\title{
視診上喉頭蓋囊胞が疑われた声門上癌例
}

$$
\begin{aligned}
& \text { 清 水 雅 子. 油 井 健 宏. 岡 田 達 佳 } \\
& \text { 加 藤 久 幸. 櫻 井一 生.内藤 健 晴 }
\end{aligned}
$$

\section{A Case of Supraglottic Carcinoma Differentiation with an Epiglottis Cyst by Ocular Inspection}

\section{Masako Shimizu, Takehiro Yui, Tatsuyoshi Okada, Hisayuki Kato, Kazuo Sakurai and Kensei Naito}

The frequency of a supraglottic carcinoma as an occult primary of cervical lymph node metastasis is high therefore such cervical lymph node involvement is an early symptom.

Our study will reference a difficult case of supraglottic carcinoma that ocular inspection assisted in differentiation on the tongue side of the epiglottis base which is a rare site of origin. With this case,a 59 -year-old man,the chief complaint was a mass on the lower left-side of his chin. He noticed a sudden increase in size of this mass and consulted with another hospital's otolaryngology department. Aspiration biopsy cytology was performed on the mass and a squamous cell carcinoma (SCC) was diagnosed.

He was introduced to this hospital with occult primary cervical metastatic cancer of the lymph node without having had the primary tumor identified yet by medical examination. PET-CT imaging revealed abnormal accumulation in the cervical lymph node to the left of the vallecula. We performed a biopsy from the lesion which seemed to be an epiglottic cyst. Because SCC was diagnosed,we took the epiglottic cyst to be the primary tumor of the cervical lymph node metastasis. We performed a horizontal partial laryngectomy and left neck dissection,followed postoperatively by radiation 60 Gy treatment. There Has been to recurrence of the primary tumor nor metastasis as of two year and four months since surgical treatment.

Key words : supraglottic carcinoma, epiglottis cyst, PET-CT

\section{は じめに}

声門上癌は, 声門癌に比べ病初期の自覚症状に乏しく, 頸部リンパ節転移の頻度も高いため原発不明頸部転移癌の 隠れた原発巣となる可能性がある。また，その発生部位は 仮声帯や喉頭蓋前庭部に多く, 喉頭蓋舌根面に発生するこ とはまれである。今回我々は，原発不明頸部転移癌と診断 され，視診上は喉頭蓋囊胞が疑われた声門上癌の 1 例を経 験したので文献的考察を加え報告する.

症例

\section{症例 : 59 歳男性}

主訴：左顎下部腫瘤

既往歴 : 頸椎損傷, 高血圧, 胃潰瘍

家族歴：特記すべき事項なし

喫煙歴：20本/日× 38 年

飲酒歴: 缶ビール $(350 \mathrm{ml}) 1$ 本/日 $\times 38$ 年

現病歴：2 力月前から急激に増大寸る左顎下部腫瘤を自 覚し, 他院耳鼻咽喉科を受診した。左顎下部腫瘤より穿刺
吸引細胞診が施行され，扁平上皮癌と診断された。視診及 び画像診断上，頭頸部領域に明らかな原発巣を認めず，原 発不明頸部転移癌と診断され, 当科に紹介受診となった。

初診時所見と経過：視診上, 鼻腔, 口腔, 咽頭には原発 巣と思われる腫瘍性病変を認めなかった。喉頭蓋舌根面に は視診上喉頭蓋囊胞が疑われる腫瘤を認めた（図 1)が, 喉頭内腔には異常所見はなかった。頸部触診では, 左顎下 部に $50 \times 40 \mathrm{~mm}$ 大の可動性良好な弾性硬の腫瘤と腫大し た左頸部リンパ節を複数触知した。血液生化学検査では, SCC 抗体が $2.7 \mathrm{ng} / \mathrm{ml}$ と高值であった以外は, 異常は認め なかった，喉頭蓋舌根面の腫瘤は表面平滑で視診上は喉頭 蓋囊胞と診断したため, 初診時には原発巣の確認はできな かった。また，顎下部腫瘤は触診上，顎下腺腫瘍との鑑別 が困難であったため, 顎下腺癌とその頸部リンパ節転移も 念頭に入れ精査した.

原発巣検索のために行ったPET-CTでは，全身の他部位 には異常集積を認めなかったが, 左顎下部腫瘤, 左頸部リ ンパ節以外に舌根部〜喉頭蓋谷にFDGの異常集積 （SUVmax5.6）を認めた（図 2)。そこで, 視診上喉頭蓋囊 

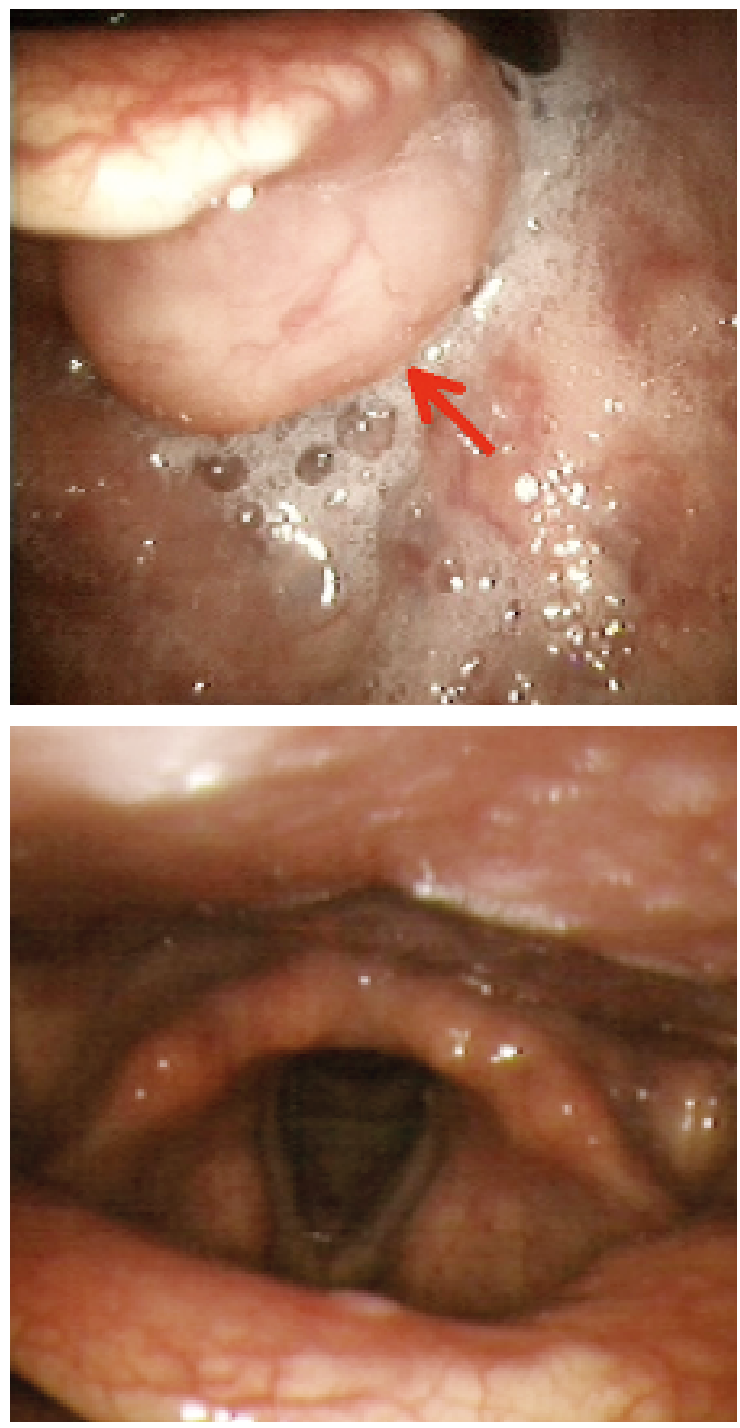

図 1 喉頭蓋舌根面には視診上喉頭蓋囊胞と思われる腫瘤 を認める。

胞と思われた喉頭蓋舌根面の腫瘤の検索を行うために頸部 造影 $\mathrm{CT}$ 検査を行った。頸部造影 $\mathrm{CT}$ では，喉頭蓋腫瘤に 一致し造影効果のある腫瘍性病変を認めた（図 3 )。確定診 断のため喉頭直達鏡下に病変の確認と生検を行った。

喉頭直達鏡所見では，腫瘤は喉頭蓋舌根面に限局してお り，20×20mm大，表面平滑でやや固い腫瘤であった． 腫瘤からの生検の結果，中～低分化型の扁平上皮癌と診断 されたため, 喉頭蓋舌根面の腫瘤が頸部リンパ節転移の原 発巣と判断し, 声門上癌 T $1 \mathrm{~N} 2 \mathrm{bM} 0$ stage IV A と診断した. 局所所見より喉頭水平部分切除の適応と判断し, 喉頭水平 部分切除術及び左保存的頸部郭清術を施行した、レベル I $\sim \mathrm{V}$ を郭清し，顎下腺は合併切除した，胸鎖乳突筋，副神 経および内頸静脈は温存した

手術所見：手術は左保存的左郭清術（レベル I〜V) を 行った後に気管切開を施行した，その後，前頸筋を舌骨下 で切断，舌骨直下やや右側より舌根部にアプローチし，下

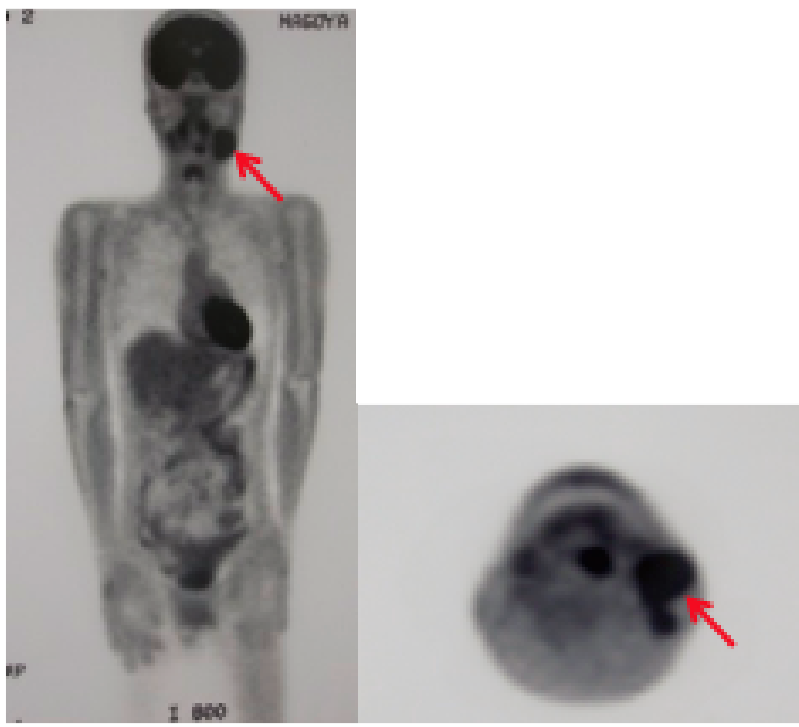

図 2 左顎下部腫瘤, 左頸部リンパ節以外に舌根部〜喉頭蓋谷 にFDGの異常集積 (SUVmax5.6) を認めた.
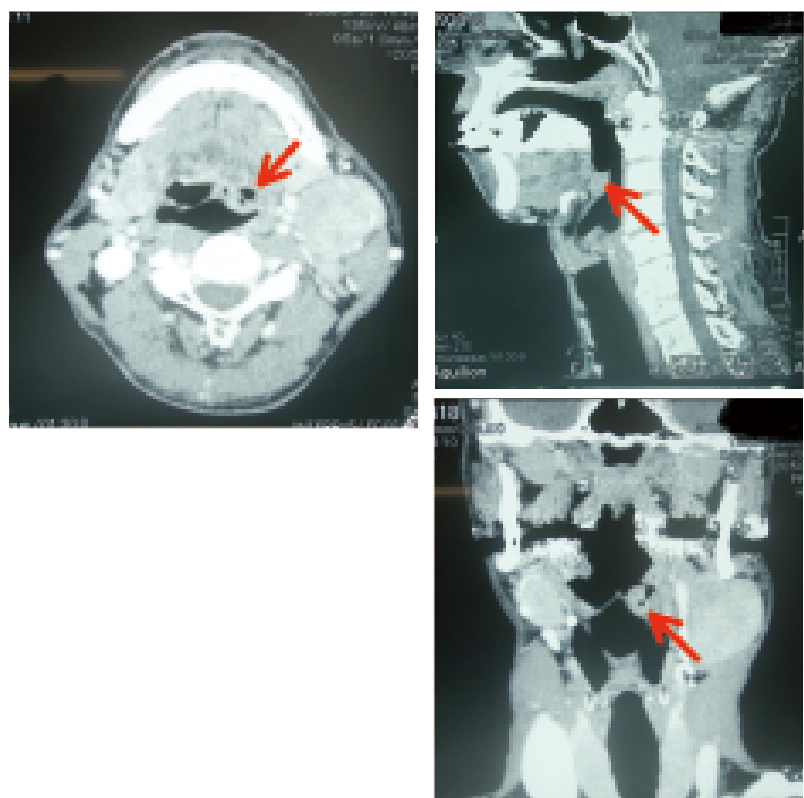

図 3 頸部造影 $\mathrm{CT}$ では，喉頭蓋腫瘤に一致し造影効果のある 腫瘍性病変を認めた。

咽頭腔を前方より開放した。喉頭蓋の腫瘍を明視下にお き，喉頭蓋とともに腫痬を摘出した，腫瘍摘出後は舌根部 と喉頭を 3 針縫合し，甲状軟骨と舌骨，舌骨と下顎骨を縫 縮して喉頭挙上術を行なった，摘出標本では，腫瘍は喉頭 蓋舌根面のやや左側に認められた (図 4).

頸部リンパ節 9 個に転移を認めたため, 術後照射 $60 \mathrm{~Gy}$ を施行した。術後 1 週間目で経口摂取を開始，誤與なく経 口摂取も可能であり，術後 4 週目で気管孔を閉鎖した。経 過は良好であり，術後 2 年 4 カ月を経過した現在，再発お よび転移は認めていない 

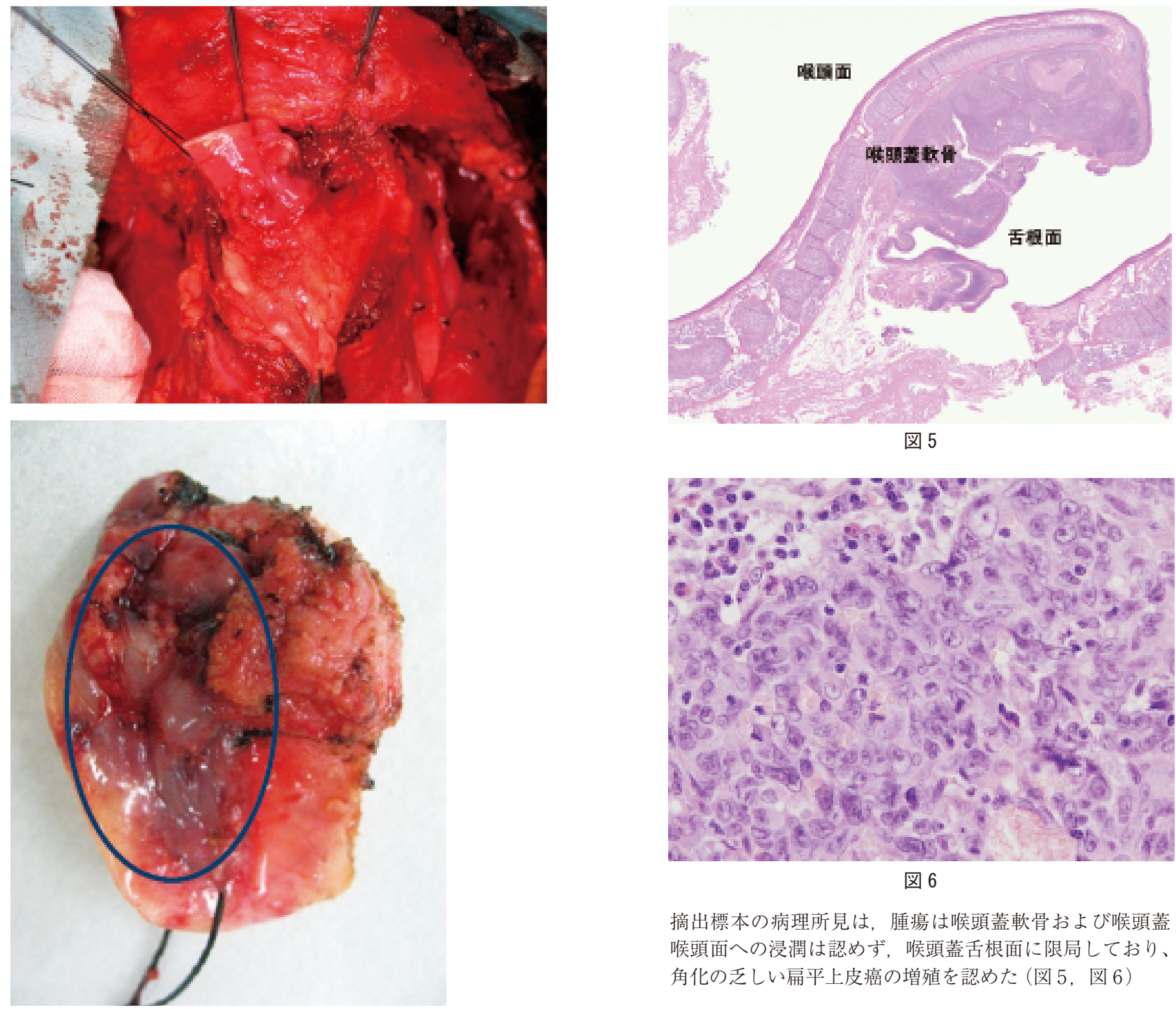

図 5

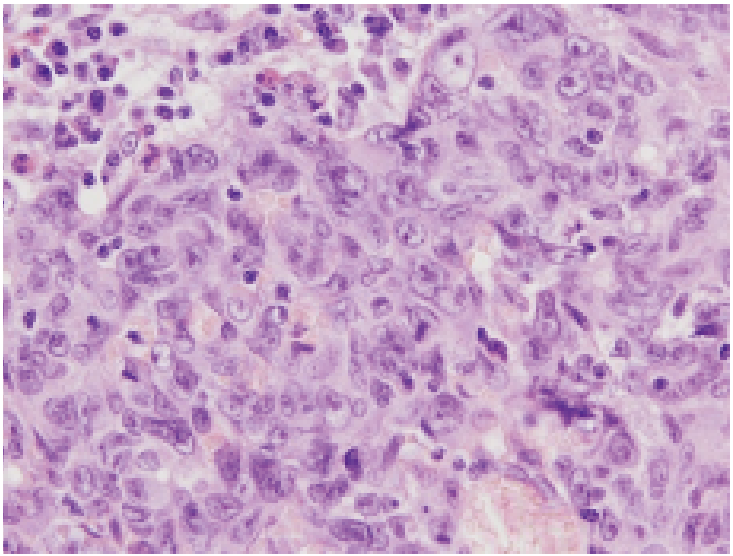

図 6

摘出標本の病理所見は, 腫瘍は喉頭蓋軟骨および喉頭蓋 喉頭面への浸潤は認めず，喉頭蓋舌根面に限局しており、 角化の乏しい扁平上皮癌の増殖を認めた（図 5, 図 6)

図 4 甲状軟骨と舌骨, 舌骨と下顎骨を縫縮して喉頭挙上術を 行なった，摘出標本では，腫瘍は $28 \mathrm{~mm}$ 大, 喉頭蓋舌根 面のやや左側に認められる.

病理組織所見：生検時の病理所見は, 明瞭な核小体を 有する腫大した核を持つ腫瘍細胞が不明瞭な胞巣構造を 形成しつつ増殖し, 中〜低分化型の扁平上皮癌と診断さ れた（図 5 )。摘出標本の病理所見は，腫瘍は喉頭蓋軟骨 および喉頭蓋喉頭面への浸潤は認めず，喉頭蓋舌根面に 限局しており，角化のそしい扁平上皮癌の増殖を認めた (図 6).

\section{考察}

声門上癌は, 喉頭癌の約 30\%を占めるが, 声門癌に比 へ，病初期の自覚症状にそしく，頸部リンパ節転移の頻 度も高率であり，進行癌が多いのが特徴である ${ }^{1)}$ 。頭頸部 癌取り扱い規約 ${ }^{2)}$ では, 声門上部は解剖学的に舌骨上喉 頭蓋 (先端, 舌面, 喉頭面), 披裂喉頭蓋ヒダ (喉頭面), 披裂，舌骨下喉頭蓋，仮声帯の 5 つの亜部位に分類され

ているが，声門上癌は喉頭蓋喉頭面や仮声帯から発生す ることが多い。 頴川 ${ }^{3)}$ は, 声門上癌 56 例の発生部位を検 討し, 仮声帯 23 例 $41.1 \%$, 舌骨下喉頭蓋 16 例 $28.6 \%$, 喉頭室 6 例 $10.7 \%$ ，披裂喉頭蓋ヒダ 5 例 $8.9 \%$ ，披裂 3 例 $5.4 \%$, 舌骨上喉頭蓋舌面 3 例 $5.4 \%$ であったと報告し ている。自験例のように喉頭蓋喉頭面には癌を認めず, 舌面にのみ癌が発生することはまれであると思われた。

初診時における声門上癌の頸部リンパ節転移率は, 30 〜 $50 \%$ 前後 ${ }^{1,4,5)}$ と報告され, 声門上部はリンパ網が豊富 に発達しているため, 頸部リンパ節への転移率が高いこと が知られている。特に傍声門間隙は脈管が豊富であり, 癌 が傍声門間隙に進展した場合は高率に頸部リンパ節転移 が生じる ${ }^{6)}$. 一般に, T分類の進行に従い頸部リンパ節転 移率も高くなるが, 梅野 ${ }^{7)}$ はT1 11 例中 2 例 $18.2 \%$, T2 92 例中 15 例 $16.3 \%$ に初診時すでに頸部リンパ節 転移を認めていたと報告している。このように局所進行 が少ない声門上癌でも少なからず頸部リンパ節転移が生 じるため，喉頭ファイバーを用いても喉頭所見がとりに 
くい症例や自験例のように視診上良性病変との鑑別が困難 である症例では, 原発不明頸部リンパ節転移癌の原発巣と なる可能性があるものと思われた。

原発不明頸部転移癌は全頭頸部癌の約 1〜5\%を占め ${ }^{4)}$, 男性に多く，組織学的には扁平上皮癌が多いことや，転移 リンパ節が大きく腫大し初回治療時すでに N 2 以上の進行 例が多いことが特徵とされている ${ }^{8)}$ 。また，転移リンパ節 は上・中内深頸リンパ節に多く ${ }^{9,10)}$, 同部位に転移リンパ 節が認められた場合には，上咽頭，扁桃，舌根，下咽頭に 原発巣が存在することが多いと言われている ${ }^{10)}$.

原発不明頸部転移癌の原発部位の検索には, 内視鏡検 查, 各種画像診断, 盲目的生検などが行われているが, 治 療中や治療後に原発部位が判明する症例が少なからず認め られる。田川ら ${ }^{11)}$ は 28 例中 7 例 $25.0 \%$, 坂本ら ${ }^{8)}$ は 39 例中 12 例 $30.8 \%$, 山西ら ${ }^{12)}$ は 14 例中 7 例 $50.0 \%$, 竹村 $ら^{10)}$ は 19 例中 11 例 $57.9 \%$ に原発部位が判明したと報告 している。判明した原発部位は，中咽頭が多く，中でも口 蓋扁桃が最も多い. 原発不明頸部転移癌の原発部位の検索 には口蓋扁桃摘出術が有用であるとする報告が多くみら $れ^{8,10,11)}$, 坂本 $~^{8)}$ は, 扁桃癌は粘膜下病変や微少病変の ことがあり，生検では診断できないことがあるため，上中 内媣頸部リンパ節が中心の原発不明頸部リンパ節癌の場合 は，口蓋扁桃摘出術を行うべきと述べている。

原発巣検索に対するFDG-PETあるいはPET-CTの意義 や有用性については多くの報告があり，CTやMRIに比し 検出能に優机有用性があるという見解と， あまり有用性が ないという見解が認められるが，最近の本邦における報告 では極めて有用であるとする報告は少ない．FDGの集積に より原発巣が判明できたとする報告の頻度をみてみると, 山西ら ${ }^{12)}$ は 14 例中 3 例 $21.4 \%$, 長谷川ら ${ }^{13)}$ は 15 例中 4 例 $26.6 \%$ であり，原発巣が判明する例は認められるがいず れも極めて有用性が高いとはいえないと述べている。一方， 石永ら ${ }^{14)}$ は 8 例, 田川ら ${ }^{11)}$ は 7 例, 猪原 ${ }^{15)}$ は 9 例にFDGPETあるいはPET-CTを行ったが原発部位が判明した症例 はなかったと報告している。その理由として，猪原 ${ }^{15)}$ は 頭頸部領域にはFDGの生理的集積が多いこと，原発不明 癌症例は原発巣が小さく描出困難であることなどを指摘し ている。また，田川ら ${ }^{11)}$ はFDG-PETを施行する際には， 正診率をあげるためPET-CTを行うべきと指摘しており， 頭頸部原発腫瘍の場合, 内視鏡で診断が困難な粘膜下病変 の検出や盲目的生検の参考所見として利用すべきと述べて いる. 自験例では, 視診上腫瘤は喉頭蓋囊胞と思われたが, $20 \mathrm{~mm}$ 大の大きさであったことから, 原発巣の検索のため 行ったPET-CTでFDGの異常集積を認め, 確定診断に 至っており, PET-CTが原発腫瘍の診断に有用であった。

\section{ま と め}

1）視診上, 喉頭蓋囊胞との鑑別が困難であった声門上癌 の 1 例を報告した。
2) 症例は 59 歳の男性で, 当初原発不明頸部転移癌と診断 されていたが, PET-CTにより原発巣が描出され, 確 定診断に至った。

3) 水平部分切除術, 左保存的頸部郭清術, 術後照射 $60 \mathrm{~Gy}$ を施行し, 術後 2 年 4 力月経過した現在再発・転移を みとめていない.

\section{参 考 文 献}

1）宮下 弘，鈴木一元，石田正人ほか：当教室に打ける 喉頭癌治療の現況。日耳鼻 89:1767-1771， 1986.

2) 日本頭頸部癌学会／編：頭頸部癌取扱い規約 (改定第 4 版)，金原出版，東京，2005.

3）頴川一信：喉頭癌の大切片組織標本による進展形式の 検討とその治療成績。耳展 30(2)：129-153， 1987.

4）藤井隆, 佐藤武男, 吉野邦俊ほか：大阪府立成人病 センターに打ける喉頭癌 1079 例の臨床統計。日耳 鼻 $100: 856-863,1997$.

5）千々和圭一, 森一功, 梅野博仁：腫瘍進展範囲からみ た声門上癌の治療法と治療成績。日気食会報 50 (4) : 463-469, 1999.

6）千々和秀記，梅野哲義，佐藤公則ほか：声門上癌の浸 潤様式に関する病理組織学的研究. 喉頭 $15: 19-22$, 2003.

7）梅野哲義：声門上癌の臨床病理学的研究. 耳鼻臨床 $89: 263-274,1996$

8）坂本菊男, 千々和圭一, 宮嶋義巳：原発不明頸部転移 癌の臨床的検討。耳鼻臨床 98:2；157-166， 2005.

9）古後龍之介, 山内盛泰, 力丸文秀: 初診時原発不明頸 部転移癌を疑った症例の検討。耳鼻 $55: 104-111$, 2009

10）竹村考史, 緒方憲久, 湯本英二 : 原発不明癌頸部転移 癌 19 例の検討。日耳鼻 108：996-1003，2005。

11）田川崇正，冨田俊樹，山口 寛ほか：原発不明頸部転 移癌 28 例の検討。日耳鼻 $110: 506-512 ， 2007$.

12）山西貴大, 村上大造, 㝨田涼生ほか：当科に扔ける最 近 3 年間の原発不明頚部リンパ節転移癌症例の臨床的 検討．頭頸部癌 $35(1) ： 37-42 ， 2009$.

13）長谷川恵子, 川上理郎, 伊藤加奈子ほか：原発不明頸 部転移癌症例の検討。頭頸部外科 19(2)：131-134, 2009

14）石永一, 大津和弥, 小林正佳ほか：原発不明頸部転 移癌の検討。頭頸部癌 $34(3): 459-463,2008$.

15）猪原秀典：頭䅡部癌の臨床における FDG-PETの有用 性．耳鼻臨床１03：595-604，2010。

別刷請求先 $\bar{T} 470-1192$ 愛知県豊明市沓掛町

田楽ヶ窪 1-98 藤田保健衛生大学医学部耳鼻咽喉科学教室 清水雅子 